\title{
Modeling the reflection of Photosynthetically active radiation in a monodominant floodable forest in the Pantanal of Mato Grosso State using multivariate statistics and neural networks
}

\author{
LEONE F.A. CURADO ${ }^{1}$, CARLO R. DE MUSIS ${ }^{1}$, CRISTIANO R. DA CUNHA ${ }^{1}$, THIAGO R. \\ RODRIGUES ${ }^{1}$, VINICIUS M.R. PEREIRA ${ }^{1,2}$, JOSÉ S. NOGUEIRA ${ }^{1}$ and LUCIANA SANCHES ${ }^{1,3}$ \\ ${ }^{1}$ Programa de Pós-Graduação em Física Ambiental, Instituto de Física, Universidade Federal de Mato \\ Grosso, Av. Fernando Correa da Costa, s/n, Cidade Universitária, 78060-900 Cuiabá, MT, Brasil \\ ${ }^{2}$ Instituto Nacional de Pesquisas Espaciais/INPE, Centro de Rastreio e Controle de Satélites/ \\ CRC, Av. Hélio Ponce de Arruda, s/n, 78050-911 Cuiabá, MT, Brasil \\ ${ }^{3}$ Departamento de Engenharia Sanitária e Ambiental, Universidade Federal de Mato Grosso, Av. \\ Fernando Correa da Costa, s/n, Cidade Universitária, 78060-900 Cuiabá, MT, Brasil
}

Manuscript received on March 5, 2015; accepted for publication on May 4, 2015

\begin{abstract}
The study of radiation entrance and exit dynamics and energy consumption in a system is important for understanding the environmental processes that rule the biosphere-atmosphere interactions of all ecosystems. This study provides an analysis of the interaction of energy in the form of photosynthetically active radiation (PAR) in the Pantanal, a Brazilian wetland forest, by studying the variation of PAR reflectance and its interaction with local rainfall. The study site is located in Private Reserve of Natural Heritage, Mato Grosso State, Brazil, where the vegetation is a monodominant forest of Vochysia divergens Phol. The results showed a high correlation between the reflection of visible radiation and rainfall; however, the behavior was not the same at the three heights studied. An analysis of the hourly variation of the reflected waves also showed the seasonality of these phenomena in relation to the dry and rainy seasons. A predictive model for PAR was developed with a neural network that has a hidden layer, and it showed a determination coefficient of 0.938 . This model showed that the Julian day and time of measurements had an inverse association with the wind profile and a direct association with the relative humidity profile.
\end{abstract}

Key words: Pantanal, photosynthetically active radiation (PAR), Cambarazal, Albedo.

\section{INTRODUCTION}

The state of Mato Grosso, Brazil contains three of the main biomes of South America: the Amazon Forest, Cerrado (savanna) and Pantanal (Rodrigues et al. 2013, 2016, Curado et al. 2014). These last two biomes are of interest to researchers who study the

Correspondence to: Thiago R. Rodrigues

E-mail: thiagorangel@pgfa.ufmt.br phenomena that promote balance between human and environmental activities (Silva et al. 2010). Because of energy and matter flow dynamics, the Cerrado and Pantanal are highly relevant for obtaining a deeper understanding of the processes that rule the biosphere-atmosphere interactions in all ecosystems. Wetlands, such as the Pantanal, are economically and ecologically important because 
their characteristics may strongly affect local and regional climate by interacting dynamically with the atmosphere (Ehhalt et al. 2001, Marshall et al. 2003).

The greatest regulator of microclimatic variables in the Pantanal of Mato Grosso State is its water cycle. Floods usually occur from January to April, and droughts occur from June to September (Novais et al. 2012); according to Biudes et al. (2009), the flooding pulse in this biome is the main moderating force that leads to the formation of monodominant stands composed of trees such as the Vochysia divergens (popularly known in Brazil as cambará). This species grows to a mean height of between 28 and 30 meters and shows a marked primary production. With a mean leaf area index (LAI) of 3.61 (Biudes 2008), intense radiation transmission within the canopy is required to maintain the net primary production of this forest.

The study of visible radiation in relation to its interaction with the surface is important for understanding physiological processes in plants, such as photosynthesis (Moura et al. 2001), and physical processes, such as evapotranspiration, which is a dominant energy dissipator in most wetlands. Because of the water abundance in these environments, solar energy controls other parameters, such as the water level of rivers, surface temperature, chemical composition of water (e.g., salinity), and duration and extension of the floodplain (Drexler et al. 2004). This interaction between radiation and surface can also affect other ecosystem factors, such as biomass, depth of rooting, growth form (grass versus woody tree or shrub) and functional type (deciduous versus evergreen), which in turn affect the physical parameters directly related to evapotranspiration (Da Rocha et al. 2004, Vourlitis and Da Rocha 2011, Rodrigues et al. 2014).

Photosynthetically active radiation (PAR) refers to radiation at a wavelength interval of 400$700 \mathrm{~nm}$ (Ross and Sulev 2000) that composes approximately $45 \%$ of the shortwave spectrum originating from the sun (Larcher 2000). With the increased demand to understand the interaction between PAR and the terrestrial climate system, time series of PAR measurements in different environments should be further studied. When PAR interacts with vegetation, phenomena such as reflection, transmission and absorption can be observed (Pereira et al. 2011). However, the dynamics of the physical structure of vegetation, which can be altered by deforestation or gaps in the forest, can affect the entrance of PAR into the forest canopy (Spolador et al. 2006).

The intensity of this radiation varies according to the Earth's precession movement, and in Brazil, PAR is more abundant during spring in the northeastern and midwestern regions and during summer in the southern region (Pereira et al. 2006). Within forests, PAR varies according to the rainfall cycle. According to Xiao et al. (2005), rainforests such as the Amazon Forest show a higher intensity of PAR during the dry season and a lower intensity during the rainy season.

Considering the important effect of the Pantanal on the climate of Mato Grosso State and the scarceness of information on the dynamics of PAR in this biome, the aim of this study was to describe the hourly and daily reflection of PAR above and below the canopy of a monodominant forest in a floodable area as well as the interaction between PAR and rainfall. An additional goal was to propose and calibrate a neural network to provide estimations in areas where PAR cannot be measured directly and to understand the multivariate relationships among the variables studied. In this study, we investigated the following hypotheses: (1) the measured variables occur over a significant gradient as a function of canopy height, (2) seasonality has a strong effect, and (3) a multivariate statistical model of neural networks is viable for joint and predictive analyses. 


\section{MATERIALS AND METHODS}

\section{STUDY SITE}

The study site is located at the Pantanal Barão de Melgaço SESC Private Reserve of Natural Heritage (PRNH SESC), $160 \mathrm{~km}$ south of the state capital Cuiabá, Mato Grosso State, Brazil. A micrometeorological tower was installed at a height of 32 $\mathrm{m}\left(16^{\circ} 39^{\prime} 50^{\prime \prime} \mathrm{S}, 56^{\circ} 47^{\prime} 50^{\prime \prime} \mathrm{W}\right)$ and an altitude of $120 \mathrm{~m}$. Vegetation in the region is a monodominant forest of Vochysia divergens Phol, which is locally known as cambarazal, with a canopy height that varies between 28 and $30 \mathrm{~m}$ (Curado et al. 2011, Rodrigues et al. 2011). The soil type is Haplic Gleysol.

\section{INSTRUMENTATION USED}

PAR was collected by three quantum sensors (LI190SB, LI-COR Biosciences, Inc., Lincoln, NE, USA) installed in the tower at heights of $33 \mathrm{~m}, 16 \mathrm{~m}$ and $2 \mathrm{~m}$ above the soil. At each height, two devices were placed, with one facing upwards to capture incident radiation and the other facing downwards to capture reflected radiation.

Accumulated rainfall was evaluated with a tipping bucket rain gauge, model TR-525 M (Texas Electronics, Inc., Dallas, TX, USA). All equipment was powered by two $12 \mathrm{~V}$ batteries with a capacity of $150 \mathrm{Ah}$ charged by $64 \mathrm{~W}$ solar panels. Data were processed and stored by a datalogger (CR 10X, Campbell Scientific, Inc., Ogden, UT, USA).

\section{CALCULATION OF REFLECTANCE}

Using the data of incident and reflected PAR at the three heights, the reflectance of PAR was determined by equation (1):

$$
R=\frac{P A R r}{P A R i} x 100
$$

where $\mathrm{R}$ is the reflectance of PAR (\%), PARr is the fraction of reflected PAR and PARi is the incident fraction. Incident and reflected radiation are in the same unit, $\mathrm{Wm}^{-2}$; therefore, reflectance is a dimensionless value (without unit).

MODELING

All the developed statistical procedures and programming routines were performed with the software IBM SPSS 22.0 (IBM Corp., Armonk, NY, USA) and Python (X,Y) 2.7.6.1.

The dimensionality of the temperature, relative humidity and wind speed profiles were reduced by a principal components analysis, with the number of components recommended by the Kaiser criterion (Hair et al. 1998) to optimize the raw data for modeling by the neural networks.

Neural networks can be considered exploratory analysis techniques that analyze the obtained synaptic relationships, predictive analysis techniques that perform interpolations, such as gap-filling (which leads to simple entries) or time series forecasting (with entries based on lagged variables), or a combination of both techniques (Belgrano et al. 2001). In this study, to explore the relationships between variables and obtain a viable model for eventual gap-filling, a simple multivariate network was delineated.

A neural network was proposed and validated to evaluate the direct and indirect effects of microclimate and seasonality (represented by the fractional Julian day) on reflected PAR. The temperature and relative humidity profiles had their dimensionality reduced from six to two by a principal components analysis that explained $99.925 \%$ of the total variance; the first component corresponded to a synthesis of the temperature profile, and the second component corresponded to a synthesis of the relative humidity profile. The wind speed profile was subjected to the same procedure and showed a low correlation with temperature and relative humidity; thus, its dimensionality was reduced from three variables to one principal component that explained $69.948 \%$ of the total variance. 
The linear combinations obtained from the principal components analysis and fractional Julian day were the entry variables for modeling the reflected PAR in a neutral network with a hidden layer of three units. The likelihood of the model was evaluated by a holdout cross-validation with $70 \%$ of the records for calibration and $30 \%$ for validation, thus producing a model that has a relative error of 0.914 and is consistent with the proposed objectives (Kohavi 1995).

The rain was not considered in the neural network due to its strongly asymmetrically distribution and platykurtic, which made it difficult to model its pattern and relationship with the other variables, however, its influence was evaluated in detail by statistical tests.

The values obtained for the synaptic weights revealed a direct influence of data seasonality on the temperature and relative humidity profiles, and their possible relationship to the dry and rainy seasons led to the evaluation of the influence of the water cycle using descriptive statistics and regressions (Figure 1).

\section{RESULTS AND DISCUSSION}

\section{RAINFALL AND DAILY REFLECTANCE PATTERNS}

For this study site, Novais et al. (2012) defined the rainy season as occurring from January to April and the dry season as occurring from June to September, with the remaining months acting as transition periods. Figure 2 shows the accumulated rainfall for the study period; the values were obtained from the Tropical Rainfall Measuring Mission (TRMM) satellite and validated by Danelichen et al. (2013).

The analysis of Figure 3 indicates the differences in accumulated rainfall between the rainy and dry seasons. For a better understanding of the water entrance and exit dynamics, Figure 4 shows the monthly rainfall in relation to the annual mean rainfall.

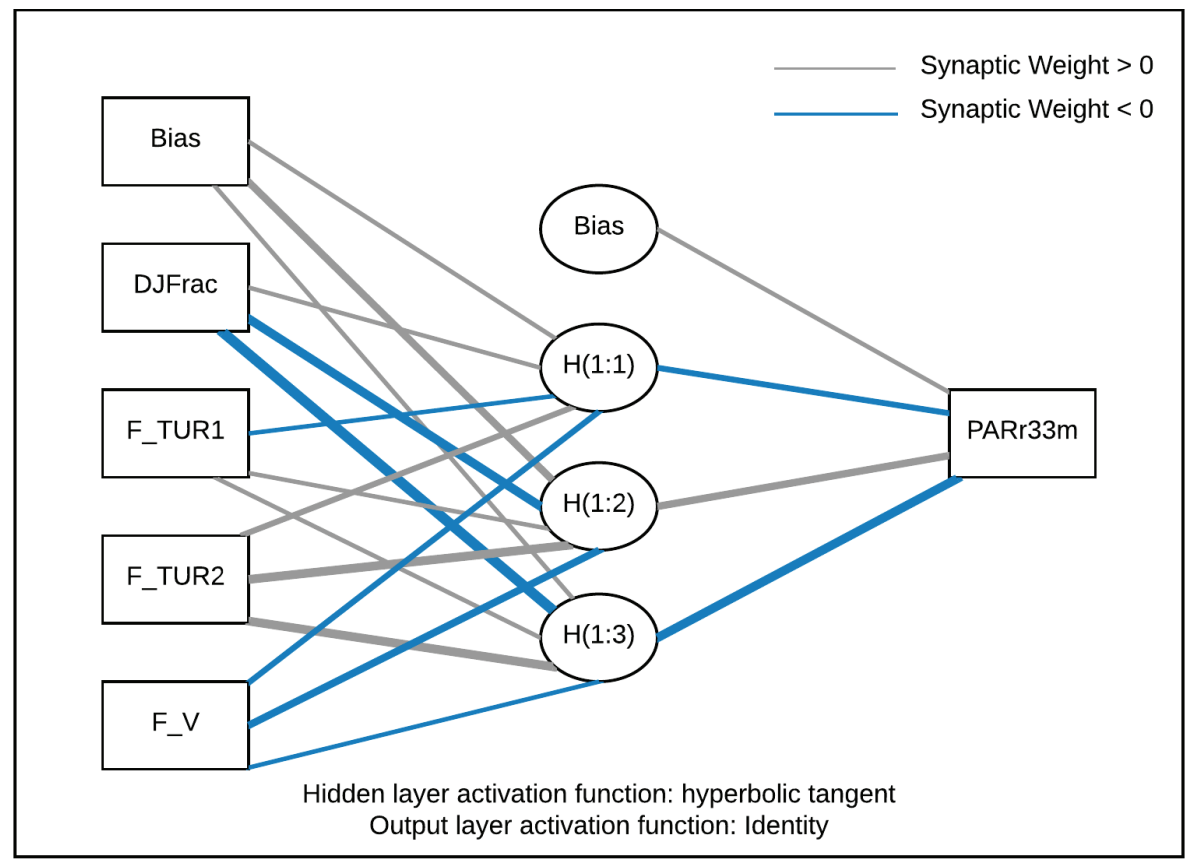

Figure 1 - Graphical representation of the neural network relating the reflectance of the radiation and indices of the temperature/relative humidity profile (F_TRH1 and F_TRH2), wind profile (F_V) and fractional Julian day (DJFrac). 


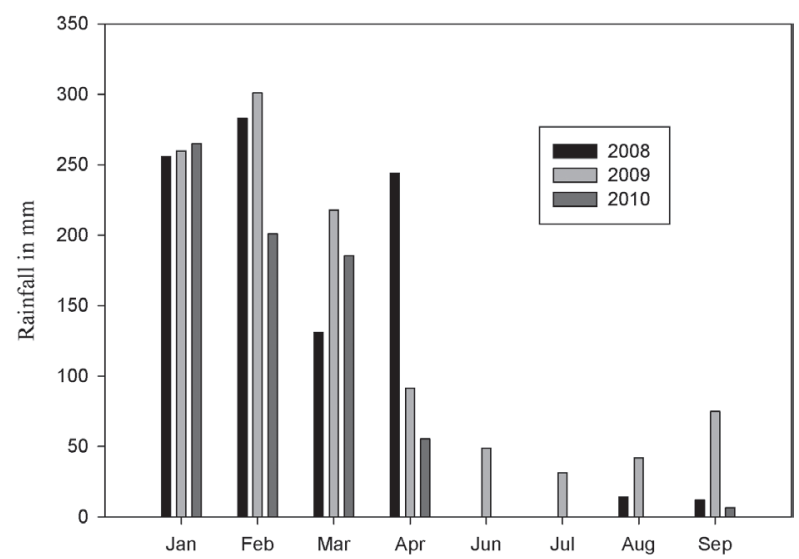

Figure 2 - Total monthly rainfall for wetlands in Mato Grosso, Brazil during the study period.

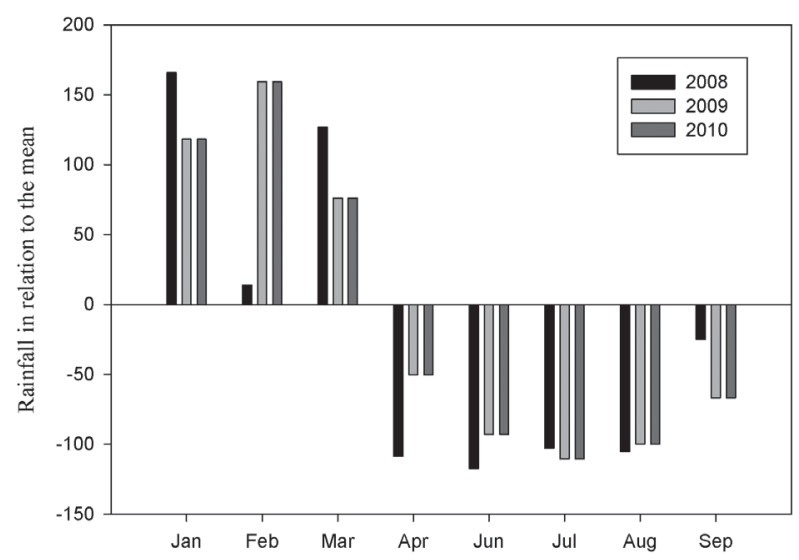

Figure 3 - Representation of the surplus/deficit of monthly rainfall in relation to the annual mean rainfall for the years 2008 to 2010 .

In certain biomes of Mato Grosso State, the dry season promotes a protection mechanism in plant species, such as a loss of leaves. According to Sanches et al. (2008), because of the water deficit in this period, this mechanism prevents severe dehydration in the vegetation.

The means of the PAR reflectance at the different heights (Figure 4) were compared by a Scheirer-Ray-Hare two-factor non-parametric analysis of variance (Sokal and Rohlf 1995), which detected a highly significant difference $(\alpha<1 \%)$ for the factors height and month and the interaction between height and month. To clarify the results obtained for the PAR reflection in the cambarazal, Figure 5 shows the monthly reflectance means at the three heights. At a height of $16 \mathrm{~m}$, the reflected radiation decreased with the transition from the rainy to dry season, indicating that additional radiation had begun to be absorbed by the forest; however, the opposite occurred at heights of $2 \mathrm{~m}$ and $33 \mathrm{~m}$, and at the lowest height, the reflectance increased to values that were higher than those measured above the canopy.

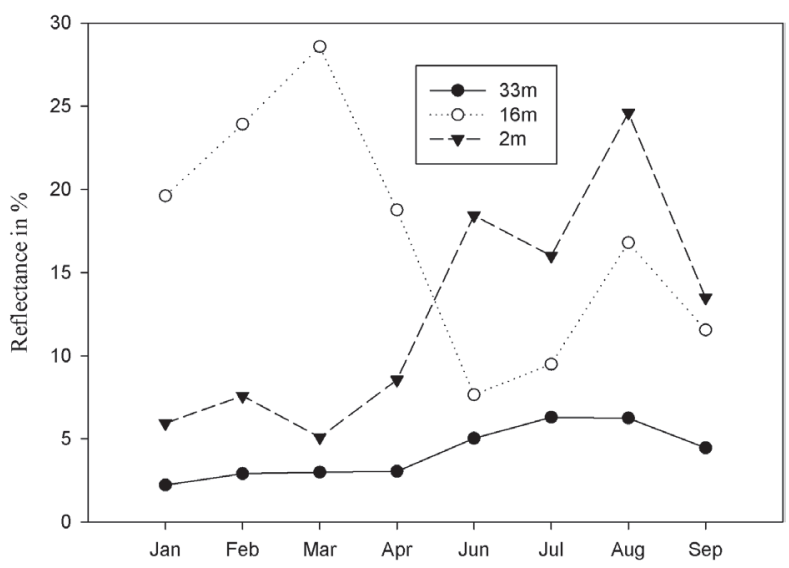

Figure 4 - Mean monthly reflectance at three heights, calculated for the years 2008 to 2010 .

Analyses of the pattern of increased reflectance for the heights $33 \mathrm{~m}$ and $2 \mathrm{~m}$ at the beginning of the dry season should consider leaf color change, a process in which the leaves age and become lighter, thus reflecting more radiation than in the previous season. Furthermore, in the dry season and under low relative humidity, the natural behavior of vegetation is to close the stomata to prevent excessive water loss to the environment, which reduces the fraction of radiation used by leaves for photosynthesis. This reasoning is consistent with the research of Amaral et al. (2006), who noted a variation in PAR at the beginning of the dry season for a perennial fruit species.

At $16 \mathrm{~m}$ of height, the reflectance within the canopy was higher during the rainy season. With the onset of drought, the values decreased; however, they subsequently showed a positive variation similar to the variation observed at the other heights. This pattern is consistent with the 
observations of Spolador et al. (2005) and was most likely related to the loss of leaves during the transition between seasons. Thus, the effective amount of incident radiation at this height changes according to the natural gaps formed in the forest, which alters the pattern of PAR reflection.

Incident radiation on leaves above the canopy was significantly higher than the incident radiation on leaves within the canopy. For the study site and period, there was a mean of $800 \mu \mathrm{mol} . \mathrm{m}^{-2} . \mathrm{s}^{-1}$ at $33 \mathrm{~m}$ compared with $287 \mu \mathrm{mol} . \mathrm{m}^{-2} \cdot \mathrm{s}^{-1}$ at $16 \mathrm{~m}$; therefore, the top of the canopy experienced 2.79 times more radiation than the canopy interior; the lower part of the forest had a mean of $87 \mu \mathrm{mol} . \mathrm{m}^{-2} \cdot \mathrm{s}^{-1}$, which was 9.20 times lower than the canopy interior. These distinct values indicate the different associations between radiation and rainfall. Figure 6 shows the types of interaction between the reflectance at the three heights and mean accumulated rainfall from the dry to rainy season.

At heights of $33 \mathrm{~m}$ and $2 \mathrm{~m}$, the patterns of association between reflectance and rainfall were the same, indicating that less radiation was returned to the environment with increasing rain. This result was possibly related to the optimization of radiation for the intense photosynthetic activity because the predominant species at the study site, Vochysia divergens, flowers at the beginning of the rainy sea-

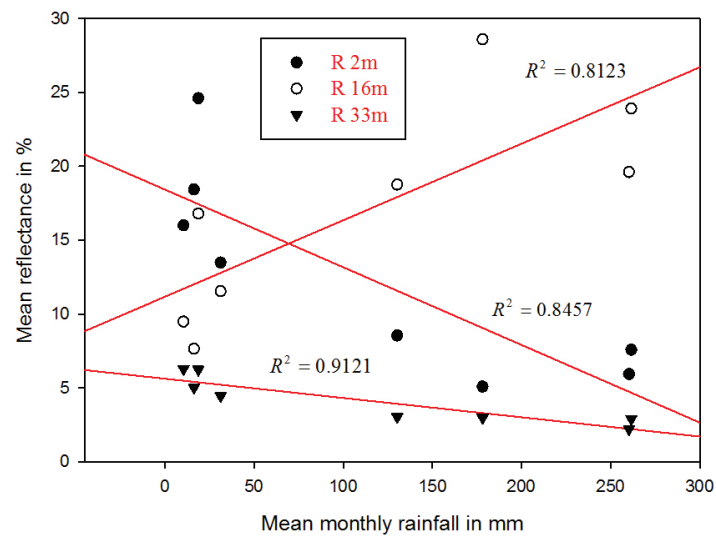

Figure 5 - Spearman non-parametric correlation and robust regression lines between mean monthly rainfall and mean monthly reflectance of PAR above the canopy $(33 \mathrm{~m})$ and below the canopy $(2 \mathrm{~m}$ and $16 \mathrm{~m})$. son, as reported by Dalmolin (2013). Therefore, considering the color of the flowers (yellow) and the occurrence of new leaves, the increased reflection may have been associated with the occurrence of these new organs, which have a high energy demand.

Another factor that can contribute to this variation is the more frequent occurrence of cloudy days during this season; Cunha (2012) studied the Cerrado of Mato Grosso and noted that sky cover is an important factor for the pattern of PAR reflection during the rainy period.

\section{HOURLY VARIATION OF REFLECTANCE}

The mean hourly reflection of PAR was calculated for the dry period. The medians corresponding to the studied heights were compared by a KruskalWallis one-way analysis of variance (Sokal and Rohlf 1995), which detected highly significant differences $(\alpha<1 \%)$. The daytime behavior pattern is represented in Figure 7. At the height of $33 \mathrm{~m}$, which is above the canopy, reflection is less variable and does not show abrupt variations during the day except from 06:00 to 06:45 and from 15:45 to $18: 00$, when the reflection pattern noticeably varies. This variation is consistent with the results of Moraes et al. (2012) and Martins et al. (2013) and is possibly associated with the beginning and end of the day.

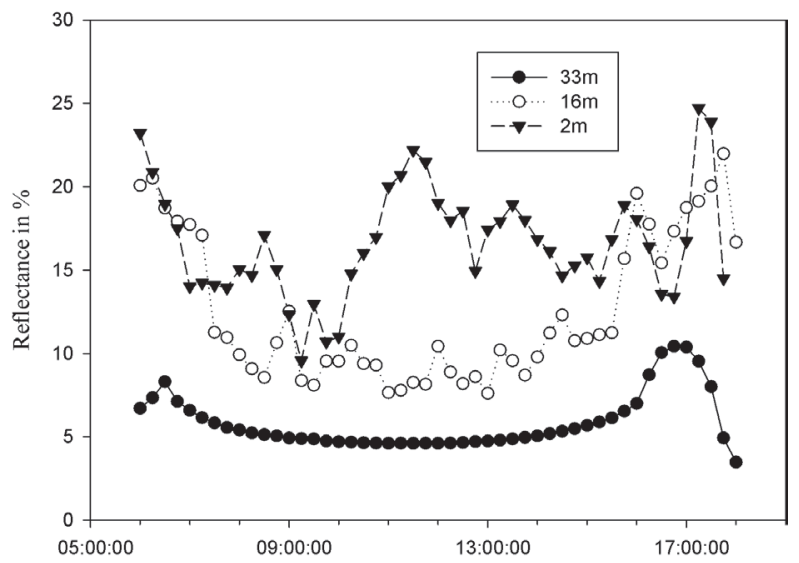

Figure 6 - Mean hourly PAR reflectance during the dry period within the canopy (16 $\mathrm{m}$ and $2 \mathrm{~m}$ ) and above the canopy $(33 \mathrm{~m})$. 
Table I shows the basic statistics of the daily data, including the maximum and minimum values found at each height. These variations during the day refer exclusively to the relationship between reflection and solar declination, as reported by Leitão et al. (2002).

TABLE I

Descriptive statistics of reflectance for the dry season.

\begin{tabular}{lccc}
\hline Height & $\mathbf{3 3} \mathbf{~ m}$ & $\mathbf{1 6 ~ \mathbf { ~ }}$ & $\mathbf{2 ~ \mathbf { ~ }}$ \\
\hline Mean daily reflectance (\%) & 5.849796 & 12.51776 & 16.67083 \\
\hline Standard deviation & 1.671594 & 4.398435 & 3.33731 \\
\hline Maximum & 10.43 & 21.98 & 24.72 \\
\hline Minimum & 3.48 & 7.61 & 9.56 \\
\hline
\end{tabular}

The highest standard deviation was observed at the height of $16 \mathrm{~m}$, followed by $2 \mathrm{~m}$, which is at the base of the forest, and the values with least variation were at $33 \mathrm{~m}$, which is above the forest canopy.

The mean values of the hourly variation in reflection differed between the rainy and dry seasons, as shown in Tables I and II. For the dry season, the decreasing order of the reflectance values was $2 \mathrm{~m}>16 \mathrm{~m}>33 \mathrm{~m}$, whereas for the rainy season, it was $16 \mathrm{~m}>2 \mathrm{~m}>33 \mathrm{~m}$, indicating that there was an inversion between the forest base and forest canopy in terms of reflectance. This inversion can be associated with the presence of a laminar water sheet because this area is a wetland that is annually subjected to complete soil flooding during the rainy season.

Although the photoperiod is longer during the rainy season, a comparison between Figures 6 and 7 shows that the variation pattern at the beginning and end of the day remained the same.

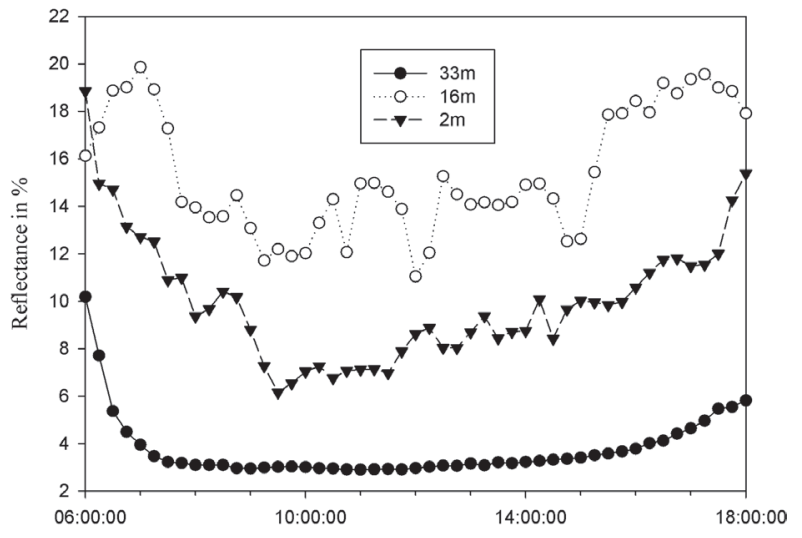

Figure 7 - Mean hourly reflectance of PAR in the rainy season within the forest canopy ( $16 \mathrm{~m}$ and $2 \mathrm{~m}$ ) and above the forest canopy $(33 \mathrm{~m})$.

\section{CONCLUSIONS}

In this study, the following characteristics of the Pantanal biome were noted.

- Rainfall was $208 \mathrm{~mm}$ for the first four months of the rainy season compared with $19 \mathrm{~mm}$ for the dry season, thus indicating a

TABLE II

Descriptive statistics of reflectance for the rainy season.

\begin{tabular}{lccc}
\hline Height & $\mathbf{3 3} \mathbf{~ m}$ & $\mathbf{1 6} \mathbf{~ m}$ & $\mathbf{2 ~ \mathbf { ~ }}$ \\
\hline Mean daily reflectance (\%) & 3.75898 & 15.4051 & 9.996531 \\
\hline Standard deviation & 1.356348 & 2.592636 & 2.649957 \\
\hline Maximum & 10.18 & 19.86 & 18.85 \\
\hline Minimum & 2.9 & 11.04 & 6.16 \\
\hline
\end{tabular}


striking difference in rainfall between these seasons.

- Reflectance values varied by height during the same season. Between the dry and rainy seasons, the reflectance values showed seasonality, with higher values on average during dry periods and lower values during rainy periods.

- A robust linear regression between reflection and rainfall produced a positive linear relationship with highly significant Spearman correlation coefficients. However, the pattern varied with height, with positive correlation occurring at $16 \mathrm{~m}$ and negative correlation occurring at $2 \mathrm{~m}$ and $33 \mathrm{~m}$.

- A predictive model was obtained by neural networks with a relative error (crossvalidation) of 0.914 and a hidden layer of three units, thus showing the influence of seasonality on the profiles, the indirect influence of the wind profile and the inverse influence of the temperature and relative humidity profiles.

\section{ACKNOWLEDGMENTS}

The research was supported by the Universidade Federal de Mato Grosso (UFMT), Programa de Pós-Graduação em Física Ambiental (PGFA) IF/ UFMT, Coordenação de Aperfeiçoamento de Pessoal de Nível Superior (CAPES), Programa Nacional de Pós Doutorado (PNPD/CAPES), and the Conselho Nacional de Desenvolvimento Científico e Tecnológico (CNPq) Process 457824/2013-1 accepted on call N॰68/2013 MCTI/CNPq/FNDCT - Ação Transversal/LBA.

\section{REFERENCES}

AMARAL JD, RENA AB AND AMARAL JD. 2006. Crescimento vegetativo sazonal do cafeeiro e sua relação com fotoperíodo, frutificação, resistência estomática e fotossíntese. Pesqui Agropecuária Bras 41(3): 377-384.

BELGRANO A, MALMGREN BA AND LINDAHL O. 2001. Application of artificial neural networks (ANN) to primary production time-series data. J Plankton Res 23(6): 651658.

BIUDES MS. 2008. Balanço de Energia em área de vegetação monodominante de cambará e pastagem no norte do pantanal. PhD Thesis, Faculdade de Agronomia e Medicina Veterinária, Universidade Federal de Mato Grosso, Cuiabá, MT, Brasil.

BIUDES MS, CAMPELO JÚNIOR JH, NOGUEIRA JDS AND SANCHES L. 2009. Estimativa do balanço de energia em cambarazal e pastagem no norte do Pantanal pelo método da razão de Bowen. Rev Bras Meteorologia 24(2): 135-143.

CUNHA CR. 2012. Influência da cobertura do céu nos albedos de uma região de cerrado da baixada Cuiabana. Dissertação de Mestrado, Instituto de Física, Universidade Federal de Mato Grosso, Cuiabá, MT, Brasil. (Unpublished).

CURADO LFA, NOGUEIRA JS, SANCHES L, RODRIGUES TR, LOBO FA AND BIUDES MS. 2014. Inter Seasonality of the Energy Fluxes in Brazilian Savana-Mato GrossoBrazil. Atmospheric and Climate Science (Online) 4: 219 230.

CURADO LFA, RODRIGUES TR, NOVAIS JWZ, DE OLIVEIRA AG, VENTURA TM, DE MUSIS CR AND NOGUEIRA JS. 2011. Adjustment of Brunt's Equation Parameters for the Northern Brazilian Pantanal. J Ecol Nat Environ 3(4): 157-162.

DALMOLIN AC. 2013. Relações hídricas, trocas gasosas e anatomia foliar de Vochysia divergens Pohl., Espécie invasora no Pantanal Mato-Grossense. PhD Thesis, Instituto de Física, Universidade Federal de Mato Grosso, Cuiabá, MT, Brasil.

DANELICHEN VHM, MACHADO NG, BIUDES MS AND SOUZA MC. 2013. TRMM satellite performance in estimated rainfall over the midwest region of Brazil. Rev Bras Climatol 12: 22-31.

DA ROCHA HR, GOULDEN ML, MILLER SD, MENTON MC, PINTO LDVO, DE FREITAS HC AND SILVA FIGUEIRA AM. 2004. Seasonality of water and heat fluxes over a tropical forest in eastern Amazonia. Ecol Appl 14: 22-32.

DREXLER JZ, SNYDER RL, SPANO D AND PAW UKT. 2004. A review of models and micrometeorological methods used to estimate wetland evapotranspiration. Hydrol Process 18(11): 2071-2101.

EHHALT D ET AL. 2001. Atmospheric chemistry and greenhouse gases. In: Houghton JT, Ding Y, Griggs DJ, Noguer M, van der Linden PJ, Dai X, Maskell K and Johnson CA (Eds), Climate change 2001: the scientific basis. Cambridge University Press, Cambridge, p. 239 287.

HAIR J, ANDERSON R, TATHAM R AND BLACK W. 1998. Multivariate data analysis, $5^{\text {th }}$ ed., Prentice Hall, Upper Saddle River, NJ, USA. 
KOHAVI R. 1995. A study of cross-validation and bootstrap for accuracy estimation and model selection. In: International Joint Conference on Artificial Intelligence 14: 1137-1145.

LARCHER W. 2000. Ecofisiologia vegetal. Rima artes e Textos, São Carlos, SP, Brasil, p. 531.

LEITÃO MVBR, SANTOS JM AND OLIVEIRA GM. 2002. Estimativas do albedo em três ecossistemas da floresta amazônica. Rev Bras Eng Agric Ambient 6(2): 256-261.

MARTINS AL, FINGER A, DA SILVA MORAES MG AND GAIO DC. 2013. Variabilidade Temporal do albedo na superficie vegetada no período seco. In: Nogueira JDS (Ed), Coletânea Física Ambiental. Editora Baraúna, São Paulo, p. 251-264.

MARSHALL J ET AL. 2003. Condamine-Balonne integrated monitoring pilot project: methods. Aquatic ecosystems technical report $n^{\circ} 41$. Queensland Department of Natural Resources and Mines, Brisbane.

MORAES MGS, FINGER A AND DE PAULO IJC. 2012. Caracterização preliminar da variabilidade sazonal do albedo da superfície no cerrado stricto sensu matogrossense. Rev Bras Cienc Ambient 26: 13-17.

MOURA MAL, LYRA RFF, BENNINCASA M, TENÓRIO RS AND NASCIMENTO-FILHO MF. 2001. Comparação da radiação solar global em áreas de floresta e pastagem na Amazônia. Rev Bras Meteorologia 16(1): 91-99.

NOVAIS JWZ, RODRIGUES TR, CURADO LFA, DE OLIVEIRA AG, PAULO SR AND NOGUEIRA JS, SAZONAL HORÁRIA DAS PROPRIEDADES V. 2012. Térmicas em gleissolo háplico no norte do pantanal. Semina: Ciências Agrárias (Impresso) 33: 2563-2570.

PEREIRA EB, MARTINS FR, ABREU SL AND RÜTHER R. 2006. Atlas brasileiro da energia solar. $1^{a}$ edição. Projeto SWERA-INPE, São José dos Campos, p. 60.

PEREIRA G, MORAES EC, ARAI E AND DE OLIVEIRA LGL. 2011. Estudo preliminar da estimativa da reflectância e albedo de microssistemas pantaneiros a partir de imagens de satélite. Rev Bras Cartografia 59(1): 55-61.

RODRIGUES TR, CURADO LFA, NOVAIS JWZ, DE OLIVEIRA AG, DE PAULO SR, BIUDES MS AND NOGUEIRA JS. 2011. Distribuição dos componentes do balanço de energia do Pantanal Mato-grossense. Rev Ciências Agro Ambientais (Online) 9(2): 165-175.

RODRIGUES TR, DE PAULO SR, NOVAIS JW, CURADO LFA, NOGUEIRA JS, DE OLIVEIRA RG, FRANCISCO A AND VOURTILIS GL. 2013. Temporal Patterns of
Energy Balance for a Brazilian Tropical Savanna under Contrasting Seasonal Conditions. Int J Atmos Sci 2013: 9.

RODRIGUES TR, VOURTILIS GL, LOBO FA, DE OLIVEIRA RG AND NOGUEIRA JS. 2014. Seasonal variation in energy balance and canopy conductance for a tropical savanna ecosystem of south-central Mato Grosso, Brazil. J Geophys Res-Biogeo 119: 1-13.

RODRIGUES TR, VOURLITIS GL, LOBO FA, SANTANNA FB, ARRUDA PHZ AND NOGUEIRA JS. 2016. Modeling canopy conductance under contrasting seasonal conditionsfor a tropical savanna ecosystem of south central Mato Grosso, Brazil. Agr Forest Meteorol 218219: 218-229.

ROSS J AND SULEV M. 2000. Sources of errors in measurements of PAR. Agr Forest Meteorol 100(2-3): 103-125.

SANCHES L, DE ANDRADE NLR, DE SOUZA NOGUEIRA J, BIUDES MS AND VOURLITIS GL. 2008. Índice de área foliar em floresta de transição amazonia cerrado em diferentes métodos de estimativa. Ciência e Natura 30(1): 57-69.

SILVA GBS, FORMAGGIO AR AND SHIMABUKURO YE. 2010. Áreas alteradas em função de atividades antrópicas no bioma cerrado localizado no estado de Mato Grosso (MT), até o ano de 2001: uma abordagem espaço-temporal. Rev Bras Cartografia 62: 363-371.

SOKAL RR AND ROHLF FJ. 1995. Biometry: the principles and practice of statistics in biological research, $3^{\text {rd }}$ ed., State University Publishing House, Stony Brook, NY, USA.

SPOLADOR J, SANCHES L AND COSTA MH. 2006. Radiação fotossinteticamente ativa em uma floresta de transição Cerrado-Amazônica. Rev Bras Meteorologia 21: 89-95.

VOURLITIS GL AND DA ROCHA HR. 2011. Flux dynamics in the Cerrado and Cerrado-forest transition of Brazil. In: Hill MJ and Hanan NP (Eds), Ecosystem function in global savannas: measurement and modeling at landscape to global scales, CRC, Inc., Boca Raton, FL, USA, p. 97-116.

XIAO X, ZHANG Q, SALESKA S, HUTYRA L, DE CAMARGO P, WOFSY S, FROLKING S, BOLES S, KELLER M AND MOORE III B. 2005. Satellite-based modeling of gross primary production in a seasonally moist tropical evergreen forest. Remote Sens Environ 94(1): 105-122. 